Review Article

www.ijrap.net (ISSN:2229-3566)

\title{
CONCEPT OF DOSHA IN AYURVEDA: A REVIEW
}

Afroja Yeasmin Akhtar Roji ${ }^{1 *}$, Murlidhar Paliwal ${ }^{2}$

${ }^{1}$ Ph.D. Scholar, Department of Samhita and Sanskrit, Faculty of Ayurveda, IMS, BHU, Varanasi, India

${ }^{2}$ Associate Professor and Head, Department of Samhita and Sanskrit, Faculty of Ayurveda, IMS, BHU, Varanasi, India

Received on: 15/09/20 Accepted on: 15/11/20

\author{
*Corresponding author \\ E-mail: rosyafroz89@gmail.com
}

DOI: $10.7897 / 2277-4343.1106196$

\begin{abstract}
Ayurveda is the most ancient medical science, which is still in practice because of its potent clinical philosophical perspective with treatment modules. Proper knowledge about tridosha is most important factor in the field of treatment. Tridosha stands for Vayu, Pitta and Kapha. Vayu partially generates the activities of the body through ionic exchange and means as action potential. The term pitta denotes the biochemical enzymes, hormones etc. Likewise, the term kapha is implied for the fluid like substances of the body responsible for the lubrication, satiation and immunity of the body. Tridosha are the causes for origin of the body in equilibrium condition and also responsible for the initiation of all pathology inside the body. These Tridoshas are called tristhuna (three main pillar) on which body sustains. As the Loka (macrocosm) is afflicted or maintained respectively by the morbidity and normal state of wind, sun and moon, so also the adhyatma-Loka (sentient world or microcosm) is either afflicted or maintained respectively by the morbidity and normal state of vayu, pitta and kapha. So, the concept of doshas is essential to be understood for proper application of principles of Ayurveda.
\end{abstract}

Keywords: Dosha, Prakrita and Vaikrita Dosha, Srotas, Health, Disease.

\section{INTRODUCTION}

Fundamental principles hold a strong ground in Ayurveda. The aim of Ayurveda is to maintain the proper equilibrium of dosha, dhatu and mala constituents in order to preserve health of healthy person and cure a disease in diseased person. Principles of Tridosha play an important role in Ayurveda. The three dosha are already present in the body of all creatures. A physician should try to know whether they are in normal or morbid condition. Tridosha (vata, pitta and kapha) play most important role in the formation of sarira or Deha or body and also the main cause of vyadhi because of exhibiting their features (stated in abnormal condition), results (of treating these) being actually observed and because of being exhorted in the scriptures (treatise in Ayurveda). ${ }^{1}$ These three altogether are called tristhuna (three pillar) and cause of Swasthya (healthy condition) or Aarogya karanam when these are stayed in equilibrium state ${ }^{2}$. The three main fundamental functions of the body i.e. 1. Movement (Sanchalan), 2. Heat production - (Swedana), 3. Lubrication (Snehana) is maintained by Vayu, pitta and kapha respectively. These tridosha represent all definite biological processes that take place in the living body. ${ }^{3}$ The difference between a living body and dead body is due to the existence of the tridosha. It is presents in living body and it is absence in dead body. The concept of doshas, their entity and functions have been described in different Samhitas in scattered way, as like Agni, Prana and Soma etc. Therefore, this review article is an attempt to collect, compile and categorize the doshas in systematic manner and to interpret it in a simple way through the help of commentaries with its overall effects on human body which will be helpful for scholars to understand the different concepts of Ayurveda and principles of treatment of the various diseases.

\section{Concept of Dosha with Discussion}

\section{Nirukti (definition) of dosha}

In Sanskrit it means dusayantitidosha- which causes the 'Dushana' (vitiation) is called dosha. It is cause for the production of Vikara (diseases) ${ }^{4}$.

\section{Utpatti (origin) of dosha}

Manifestation of dosha is not possible until it has own Adhikarana for doing their own action. Sharira is Adhikarana (place) for dosha abhivyakti. Purusha is two type a. Virat Purusha or Vishwa Purusha or Loka Purusha or Universe and b. Purush or Rashi Purush or Human Body. Purusha is the Laghu rupa of the Loka Purusha. Purusha is nothing but the combination of shad dhatu. Just as soma (moon-water), Surya (sun-fire) and Anila (vatawind-oxygen) support the body in this world by functions like Visarga (releasing of strength), Adana (withdrawing strength) and Vikshepa (initiating all actions) respectively, similarly kapha, pitta and Anila (vata) supports the human body (with respective functions $)^{5}$. Above these three Sthoola rupa dosha from Loka Purusha are converting into Sukshma Rupa dosha in human body through Srishti utpattikram (embryogenesis) ${ }^{6}$.

\section{Characteristics of Dosha}

Characteristics of dosha are followings-

Doshas are vitiated by its own cause. Doshas by nature have the power of vitiating tissue elements? 


\section{Paramanu Swarupa (subtle form)}

Doshas are present in human body in minutest particles (Paramanu rupa).

\section{Sandarbha (References)}

a. Padartha are present in universe in two forms like- Murta and Amurta rupa. Amurta rupa has no Varna (complexion) and Rasa (taste) but Murta rupa has Varna and rasa. Doshas possess Varna (color) and Rasa (taste). So, doshas exist in Murta rupa (physical form) ${ }^{8}$.

b. Seven hundred Shiras are present in human body ${ }^{9}$. Vata, pitta and Kaphavaha Shira are among them. Shira also the synonym of srotas. Acharya Charaka did not differentiate between Shira, Dhamani and Shrota but he has described their characteristics according to their qualities such as nature of pulsating when (doshas) get filled up with nutrient material derived from external sources; subsequently, these nutrient materials are supplied to the tissues through the process of transudation and at this level, they are known as srotas. Channels belonging to third category i.e. Shira, which simply carry substances from one place to another. They do not pulsate nor does the process of transudation take place there. Shira or vessels dominantly carry each of the doshas ${ }^{10}$. The specific varieties of the variation of channels of circulation in the human body are same in number as the bhava rupa (structural entities) in the human bodies. Minutest units (cell) into which all organs of the body are divided known as Paramanu and they cannot be counted because (a) they are extremely numerous (b) they are extremely subtle and (c) they are beyond sensory perception. Vayu and the specific nature of the results of the past action associated with these Paramanu are responsible for their union and disjunction ${ }^{11}$.

c. Due to subtle form of vayu is responsible for SamyogaVibhaga, Chesta, Adhikara, Akunchana, Prasarana, formation of Koshthaanga, Dhatu and gives Chetana (life) in srotamshi ${ }^{12}$.

\section{Sarvadeha Sanchari}

Doshas move all over the body all time with its own motion (Nitya Sanchari) either in Prakrita avastha (normal condition) or Kupita avastha (vitiated condition)

\section{Sandarbha (References)}

a. Vatapittakaphadehe Sarvasrotoanusarini (vata, pitta and kapha move all over the body) and Vatapittashleshmanam punah sarvasharir charanam sarvani srotamshi-ayanbhutani (vata, pitta and kapha move all over the body; hence all the channels of the body cater to their needs for movement $)^{13}$.

b. Doshas are always situated in Aprachyuta or Avikrita avastha (normal condition according to their Swaman (own quantity) in respect to dravya, guna and karma) and it is spreading all over the body and doing their action ${ }^{14}$.

c. Diseases manifest at the place where the aggravated doshas, circulating all over the body become obstructed due to abnormality of the channels (in the dhatus/tissues) ${ }^{15}$.

d. Acharya Sushruta also said that seven hundred Shira are present in the entire human body. By these, the entire body is nourished constantly, kept lubricated/ moistened to perform actions such as flexion/ contraction/ extension etc. similar to a large field being nourished by small channels of water. Their (dosha) spreading is like the ribs in a leaf. Vata, pitta and kapha vahini siras are present among the seven hundred shiras $^{16}$. e. According to the view of other scholars mentioned in Charaka Samhita, the transformation of dhatus (from rasa to shukra) takes place in six days and nights. This process of transformation of the tissue elements requiring nourishment is a continuous one, like a moving wheel ${ }^{17}$.

f. Vyana vayu pervades all over the body with Shighra gati (fast movement) than other types of vayu ${ }^{18}$.

g. Though Tridoshas pervade all over the body in Nitya Sanchari state (healthy and diseases condition), site of manifestation of their function are called vishesha sthana (special place) of that respective doshas. As for example upper part of the Hridaya (heart) is dominated by kapha, area below the nabhi (umbilicus) is dominated by vata, area between the Hridaya and nabhi is dominated by pitta $^{19}$.

\section{No tu paraspara-upoghata}

In homeostatic condition, doshas pervade all over the body without hampering to each other qualities and functions.

\section{Sandarbha (References)}

a. Doshas are never destroyed by each other. They co-exist in a harmonious state, even though they are of mutually contradictory attributes. This happens because of their Sahaja-Satmya (natural wholesome disposition of coexistence), on the analogy of the virulent poison not causing any harm to the snake whose body contain $\mathrm{it}^{20}$.

b. Dhatus having mutually opposite qualities undergo increase and decrease condition simultaneously. A thing which increases a particular dhatu is also responsible for the decreasing of the dhatu of opposite quality. Through this principle homeostatic condition of health is maintained ${ }^{21}$.

\section{Deha-Dharana}

Doshas are support of the body.

\section{Sandarbha (References)}

a. According to Acharya Charaka when dosha, dhatu, mala all are staying in equilibrium condition then it is responsible for Swasthya. For this equilibrium condition doshas are also named as Dhatu ${ }^{22}$.

b. Just as Soma (moon-water), Surya (sun-fire) and Anila (airoxygen) support the body of this world by functions like Visarga, Adana and Vikshepa respectively, similarly kapha, pitta and vata support this human body (with respective functions $)^{23}$.

c. Dhatu consists of vata, pitta, kapha, rasa, rakta, mamsa, meda, Asthi, majja and shukra ${ }^{24}$.

\section{Deha-Sambhava hetu}

Doshas are the cause for origin of the body.

\section{Sandarbha (References)}

a. The body can never be formed without kapha, pitta, Maruta (vata) and even Shonita (blood); body is always supported by these ${ }^{25}$.

b. Vata, pitta and Shleshma are the prime factors for origin of body, when they are staying in normal condition and spread all over the body with direction (lower, middle and upper parts of the body). Body is supported just like the house being supported by the three pillars; hence it is known tristhuna (three pillars) $^{26}$. 
c. Prakrita doshas help in genesis of Garbha with the help of shukra and shonita ${ }^{27}$.

d. Dosha, dhatu and mala are the main cause of Deha or body from birth to death ${ }^{28}$.

\section{Vyadhi-utpadak hetu}

Doshas are the main seed for origin of diseases.

\section{Sandarbha (References)}

a. Rogastu doshavaisamyam-disequilibrium condition of doshas is responsible factors for the production of diseases ${ }^{29}$.

b. For all diseases, vata, pitta and Shleshma only are the cause because of exhibiting their features, result (of treating these) being actually seen/observed and because of being exhorted in the scriptures ${ }^{30}$.

c. All the bodily diseases arising out of the disturbance of the equilibrium of dhatus are ultimately caused by nothing else but the disorder of pitta, kapha and vata ${ }^{31}$.

\section{Types of dosha}

Doshas are described in many ways such as sharir-dosha and manas-dosha; Prakrit-dosha and Vaikrita-dosha and so on. Brief description of the types of doshas is been given here.

\section{Sharir-dosha}

Vayu, pitta and kapha are called sharir-dosha which constitutes the pathogenic factors of the body. These three doshas play an important role in the formation of Garbha sharir. Commentator Chakrapani said that if these three doshas are aggravated with companionship or all together at a time according to their mana (Dravyah, Guntah and Karmatah) then Garbha-sharir will not formed. These three doshas are pertaining to the body. Diseases caused by them are Jwara (fever), diarrhea, edema, dyspnoea, Meha (obstinate urinary disorder including diabetes), kustha (obstinate skin disorders including leprosy) etc ${ }^{32}$.

\section{Manas-dosha}

Rajas and tamas are the doshas which constitute the pathogenic factors of mind and the types of morbidity caused by them are Kama (passion), anger, greed, attachment, envy, ego, pride, grief, worry, anxiety, fear, excitement etc ${ }^{33}$.

\section{Prakrit dosha}

When doshas are staying in balance condition according to their Swaman (in respect to its quantity, quality and function) and doing all their respective functions properly without hampering their normal respective functions according to Jati (race) vaya (age), Desh (habitat), kala (time) etc. then they are termed as
Prakrita dosha ${ }^{34}$. Doshas enter into Garbha during ShukraShonita samyoga (fertilization) and get nourishment from ahara rasa of Garbhini. These Prakrit dosha influenced very deeply and in subtle level but without changing their underlying values. By the help of Prakrita dosha nourishment of fertilized ovum or zygote, cell division, production of organ and development take place. ${ }^{35}$.

\section{Vaikrita Dosha}

After birth, due to proper following of diet and daily regimen dosha produced in the living body and regulates its physiological process. These are called Vaikrita dosha. It is also two types Shareerika dosha - vata, pitta \& kapha \& Manasika dosha - rajas $\&$ tamas. During the process of digestion (process of transformation of food) kapha is produced in amasaya, similarly pitta is produce in grahani and vata is produced in pakwashaya in sequential manner. Through the process of avasthapaka and nisthapaka, the digested food materials with the help of Dhatwagni (Rasagni or Raktagni etc.), kapha and pitta are converted into kitta bhaga of rasa dhatu and rakta dhatu respectively. These Vaikrita dosha which are produced from ahara rasa due to similarity (uniformity) with Prakrita dosha, it nourishes the Prakrita dosha homogenously ${ }^{36}$. As long as these three doshas are produced in proper quantity along with their qualities or stay in normal (Sama or balance) condition, they help to maintain normal physiological process. But if doshas are going into kshina and vriddhi (excessively) states according to their Dravatah, Gunatah and Karmatah then they hamper homeostasis of the body and produce diseases ${ }^{37}$. Doshas are classified into Prakrita (in normal state of dosha - daily or seasonal variation of doshas); and Vaikrita (in vitiated state- aggravation of kapha and vata in Vasanta Ritu and Pravrit Ritu respectively in which treatment in terms of Vaman, Virechan etc. were needed), SamaNiram, Anubandhya (doshas which have proper sign, aggravated by their own causes and pacify through following treatment of principle which has been mentioned in Shastra)- anubandha (opposite of Anubandhya), ashayaapkarsa Prakriti- Vikriti etc ${ }^{38}$.

\section{Sandarbha (references)}

a. Doshas when aggravated; manifest their sign and symptoms in accordance with the degree of aggravation; those in the state of diminution give up their normal signs and symptoms; and those in a state of equilibrium operate properly ${ }^{39}$.

b. During the normal state of Tridoshas they sustain body. When vitiated, they afflict the body with the various type of diseases $^{40}$.

\section{Gati of Dosha}

Gati (dimension) of the doshas has been described in different Ayurvedic compendium, which mentioned below in schematic diagram (Figure 1)..$^{41-43}$ 


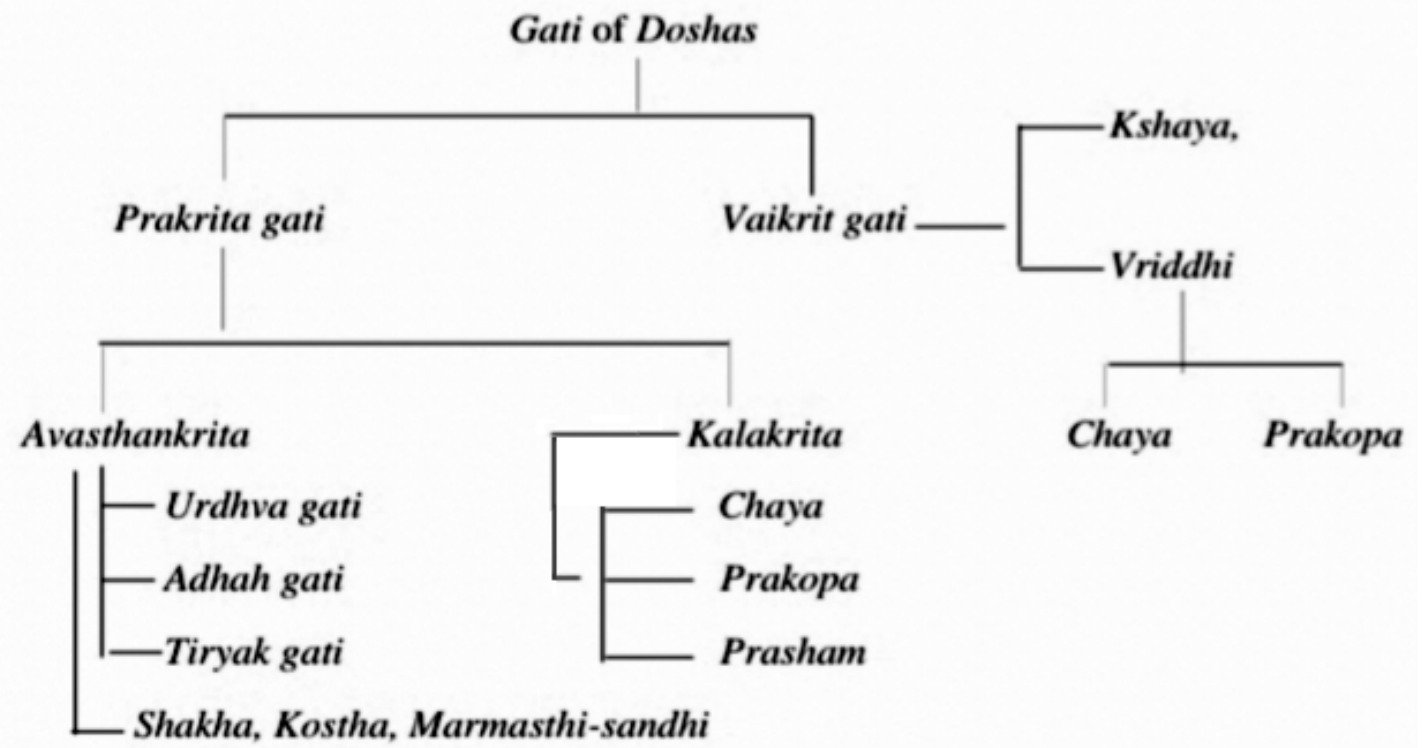

Figure 1: Different types of gati of doshas

Figure 1: Different types of gati of doshas

\section{Avastha of Dosha}

According to yoni avastha or condition of dosha are two 1 . Prakrita and 2. Vaikrita avastha. Prakriti avastha of doshas depend on sperm and ovum and ahara rasa taken by mother. Vaikrita avastha of doshas depend on ahara and regimen of the individual. Origin of Vaikrita dosha occurs in Mahasrota (during the process of digestion). Depending on Ahara Matra and Agni, is divided into two types -1. Amavastha 2. Niramvastha. Depending on Ahara paka (process of digestion, metabolism and absorption), these are also divided into two - Prasadavastha (pure substance) and kittavastha (metabolites/impurities). According to the Pramana these can also be divided into four types Samavastha (equilibrium condition), Kshinavastha (decreasing quantity), Vruddhavastha (increasing state) and Kupitavastha (vitiated state) condition. ${ }^{44}$

\section{Dosha Swarupa (entity of doshas)}

\section{Atma-rupa/ karma-rupa of dosha}

Classification of vayu depends on the karma. That is why description of different types of vayu are available in different text such as- according to Yoga Bindu, Yoga Shastra and Yoga Upanishad, vayu are 365, 7 and 17000 in number respectively. According to Ayurveda five types of vayu present in the body (depends on functions). If types of vayu were only five, then all Acharyas have been described only about these five types of vayu but they did not do it. Same thoughts are applicable for pitta and kapha also. So, may be types of Tridoshas are innumerable, but Acharya Charaka has depicted (in chapter 12 of sutra sthana) about the different types of functions of vayu such normal, abnormal function apart from their types. Similarly, in case of pitta and kapha same thoughts are applicable ${ }^{45}$.

\section{Dhatu-rupa dosha}

Maintenance the dhatu samya (equilibrium condition) is the main aim of Swastha (health). Any disturbance in the equilibrium of dhatus is known as disease and on the other hand, the state of their equilibrium state is termed as health. Health and disease are also defined as pleasure and pain respectively. Here dhatus consist of vata, pitta, kapha, rasa, rakta, mamsa, meda, asthi, majja and shukra and Upadhatu like rajas etc ${ }^{46}$.

\section{Dosha-rupa dosha}

By nature, vata pitta and kapha are vitiators. After getting vitiated (by endogenous and exogenous factors), they vitiate other factors of the body and manifest different sign and symptoms of the vitiation according to their pathologic state ${ }^{47}$. Tridoshas only can vitiate all the dhatus throughout the body, but Rasadi dhatus are cannot vitiate doshas in any condition/circumtances ${ }^{48}$.

\section{Prakriti-rupa dosha}

Prakriti rupa dosha are produced from the parents during embryogenesis and also responsible for the production of prakriti (genetic constituents) of upcoming offspring ${ }^{49}$.

\section{Dravya-rupa dosha}

Tridoshas are also known as dravya because they are substratum of qualities and actions and concomitant cause of the Padartha (matter). Following characters are present in dosha in terms of dravya which have been mentioned below-

a. Number of Shareerika dosha is three ${ }^{50}$.

b. Every dravya (matter) has its own qualities and actions which stay in it in Samvayi (inseparable) relation ${ }^{51}$. Similarly, doshas also have qualities and functions with inseparable relation in the body.

c. Amount of doshas have been described in Charaka Samhita sharir sthana - i.e. kapha- 6 anjali and pitta 5 anjali ${ }^{52}$.

d. Doshas are Paramanu Swarupa (subtle in nature) ${ }^{53}$.

e. Structural entities are main characteristic of bhava or murtimanto padartha. As for example, Shleshma is formed by the combination of Prithvi and Ap mahabhutas ${ }^{54}$. 


\section{Mala-rupa dosha}

When doshas are situated in Prakupita avastha (aggravate condition) then they termed as mala.

\section{Sandarbha (References)}

a. Attributes of the body are again two categories viz Prasad (pure substance) and kitta bhaga or mala (metabolites/impurities). Among them, which impurity afflicts the body with pain are known as mala. When putrefied tissue elements of the body, vitiated vata, pitta and kapha, such other substances etc. are existing into the body and producing diseases or any abnormalities or destruction of Deha then they can be categorized under the group of mala ${ }^{55}$.

b. Bhutabhisangaja Jwara has been described in compendium, which was originated from the vitiation of vayu, pitta and kapha. In this context vata, pitta and kapha were designated as mala ${ }^{56}$

\section{CONCLUSION}

Tridosha are the basic doctrines of Ayurveda on which health or ill-health depends. The term 'tridosha' stands for vayu, pitta and kapha. On the basis of above discussion, it has been cleared that those factors which regulate normal physiological activities of the body and have control over it, which cause the specific constitution of the body and which can independently vitiate the others factors of the body due to their alteration are known as doshas in Ayurveda.

\section{REFERENCES}

1. Acharya Trikamji Yadavji, Sushruta-Samhita (NibandhaSamgraha Commentary of Dalhana and Nyayachandrika Panjika of Gayadas on Nidana sthana), Sutra sthana, Vranoprasniya Adhyayam- 21/3-4, Published byChaukhambha Orientalia, Varanasi; reprint; 2002. p. 99.

2. Hari Sadashiva Shastri Paradakara, Ashtanga-Hridaya (Sarvanga Sundari and Ayurveda Rasayana Commentary), Sutra sthana, Chapter 12/77; Published by- Chaukhamba Sanskrit Sansthan, Varanasi, reprint; 2018. p. 210.

3. Acharya Trikamji Yadavji, Sushruta-Samhita (NibandhaSamgraha Commentary of Dalhana and Nyayachandrika Panjika of Gayadas on Nidana sthana), Sutra sthana, Vranoprasniya Adhyayam-21/4, Published byChaukhambha Orientalia, Varanasi; edition; 2002. p. 99.

4. K. R. Srikanta Murty, Sharangadhar Samhita, Prathama Khanda, Doshadi vijnan-4/46; Published by- Chaukhambha Sanskrit Bhavan, Varanasi, edition; 2009. p. 22.

5. Acharya Trikamji Yadavji, Sushruta-Samhita, (NibandhaSamgraha commentary of Dalhana and Nyayachandrika Panjika of Gayadas on Nidana sthana), sutra sthana, Vranoprasniya Adhyayam-21/8; Published byChaukhambha Orientalia, Varanasi; edition; 2002. p. 100.

6. Niranjanadeba Ayuvedalamkar, Prakrita Doshavijnan, Sristivikas aur Tridosa ke mula Tatwa-7; Published byAyurvedic and Tibbi Academy Uttar Pradesh, Varanasi, edition; 1971. p. 28.

7. Acharya Yadavji Trikamji, Charaka-Samhita (AyurvedaDipika commentary), sutra sthana, Vividhashitiyapitiya Adhyayam-28/8; Published by- Chaukhamba Surbharati Prakashan, Varanasi, edition; 2000. p. 178.

8. Hari Sadashiva Shastri Paradakara, Ashtanga-Hridaya (Sarvanga Sundari and Ayurveda Rasayana commentary), sutra sthana, Doshabhediya Adhyayam-12/53; Published by-
Chaukhamba Sanskrit Sansthan, Varanasi (India), Reprint; 2018. p. 201.

9. Acharya Trikamji Yadavji, Sushruta-Samhita (NibandhaSamgraha commentary of Dalhana and Nyayachandrika Panjika of Gayadas on Nidana sthana), Sharira sthana, Shiravarnavibhaktis Sarir-7/16; Published by- Chaukhambha Orientalia, Varanasi, edition; 2002. p. 377.

10. Das Bhagwan, Charaka Samhita (text with English translation and critical exposition based on Chakrapani Dutta's Ayurveda Dipika) volume-I, Sutra Sthana, Atreya bhadrakapyiya Adhyayam-26/126; Published byChaukhambha Sanskrit series office, Varanasi, Reprint; 2018. p. 596.

11. Yadavji Trikamji Acharya, Charaka-Samhita (with the Ayurveda-Dipika commentary by Chakrapani Dutta), Sharir sthana, Sharirsamkhya Sarir-7/17; Published byChaukhambha Surbharati Prakashan, Varanasi (India), Reprint; 2000. p. 461.

12. Niranjanadeba Ayuvedalamkar, Prakrita Doshavijnan, Vatapitta-sleshma dravya yah shakti-11; Published byAyurvedic and Tibbi Academy Uttar Pradesh, Varanasi, edition; 1971. p. 73.

13. Acharya Yadavji Trikamji, Charaka-Samhita (with the Ayurveda-Dipika commentary), Vimana sthana, Srotovimana Adhyayam-5/3; Published by- Chaukhambha Surbharati Prakashan, Varanasi, Edition; 2000. p. 171.

14. Das Bhagwan, Charaka Samhita (text with English translation and critical exposition based on Chakrapani Dutta's Ayurveda Dipika), volume-II, Vimana sthana, Srotovimana Adhyayam-5/3; Published by- Chaukhambha Sanskrit series office, Varanasi, Reprint; 2018. p. 173.

15. Hari Sadashiva Shastri Paradakara, Ashtanga-Hridaya (Sarvanga Sundari and Ayurveda Rasayana commentary), sutra sthana, Dosabhediya Adhyayam-12/18; Published byChaukhambha Sanskrit Sansthan, Varanasi, Reprint; 2018. p. 195.

16. Acharya Trikamji Yadavji, Sushruta-Samhita (NibandhaSamgraha commentary of Dalhana and Nyayachandrika Panjika of Gayadas on Nidana sthana), sutra sthana, Vyadhisamuddesheeyam Adhyayam-24/10; Published byChaukhambha Orientalia, Varanasi, edition; 2002. p. 180.

17. Acharya Trikamji Yadavji, Sushruta-Samhita (NibandhaSamgraha commentary of Dalhana and Nyayachandrika Panjika of Gayadas on Nidana sthana), sharir sthana, Siravarna vibhakti Sarir-7/5; Published by- Chaukhambha Orientalia, Varanasi, edition; 2002. p. 377.

18. Yadavji Trikamji Acharya, Charaka-Samhita (AyurvedaDipika commentary by Chakrapani Dutta), chikitsa sthana, Grahani Chikitsa Adhyayam- 15/21, Published byChaukhamba Surbharati Prakashan, Varanasi (India), Reprint; 2000. p. 515.

19. Hari Sadashiva Shastri Paradakara, Ashtanga-Hridaya, (Sarvanga Sundari and Ayurveda Rasayana commentary) sutra sthana, Doshabhediyam Adhyayam-12/26, Published by- Chaukhambha Sanskrit Sansthan, Varanasi (India), Reprint; 2018. p. 193.

20. Yadavji Trikamji Acharya, editor, Charaka-Samhita (Ayurveda-Dipika commentary by Chakrapanidatta), sutra sthana, Dirghamjivitiyam Adhyayam-1/8; Published byChaukhambha Surbharati Prakashan, Varanasi (India), Reprint; 2000. p. 7.

21. Yadavji Trikamji Acharya, Charaka-Samhita (AyurvedaDipika commentary by Chakrapani Dutta), sutra sthana, Atreyabhadrakapiya Adhyayam-26/29; Published byChaukhambha Surbharati Prakashan, Varanasi (India), Reprint; 2000. p. 144-146. 
22. Yadavji Trikamji Acharya, Charaka-Samhita (AyurvedaDipika commentary by Chakrapanidatta), chikitsa sthana, Atreyabhadrakapiya Adhyayam-26/59-63; Published byChaukhambha Surbharati Prakashan, Varanasi (India), Reprint; 2000. p. 146.

23. Acharya Trikamji Yadavji, Sushruta-Samhita (NibandhaSamgraha commentary of Dalhana and Nyayachandrika Panjika of Gayadas on Nidana sthana), sutra sthana, Vranoprasniya Adhyayam-21/8; Published byChaukhambha Orientalia, Varanasi, edition; 2002. p. 100.

24. Yadavji Trikamji Acharya, Charaka-Samhita (AyurvedaDipika commentary by Chakrapanidatta), sutra sthana, Khuddak Chatushpada Adyayam-9/4; published byChaukhambha Surbharati Prakashan, Varanasi (India), Reprint; 2000. p. 63.

25. Acharya Trikamji Yadavji, Sushruta-Samhita (NibandhaSamgraha commentary of Dalhana and Nyayachandrika Panjika of Gayadas on Nidana sthana), sutra sthana, Vranoprasniya Adhyayam 21/4; Published by- Chaukhambha Orientalia, Varanasi, edition; 2002. p. 98.

26. Acharya Trikamji Yadavji, Sushruta-Samhita (NibandhaSamgraha commentary of Dalhana and Nyayachandrika Panjika of Gayadas on Nidana sthana), sutra sthana, Vranoprasniya Adhyayam-21/3; Published byChaukhambha Orientalia Varanasi, edition; 2002. p. 99.

27. Acharya Trikamji Yadavji, Sushruta-Samhita (NibandhaSamgraha commentary of Dalhana and Nyayachandrika Panjika of Gayadas on Nidana sthana), sutra sthana, chapter 21/1; Published by- Chaukhambha Orientalia, Varanasi, edition; 2002. p. 99-100.

28. Hari Sadashiva Shastri Paradakara, Ashtanga-Hridaya (Sarvanga Sundari and Ayurveda Rasayana commentary), sutra sthana, Dosadivijnaniya Adhyayam- 11/1; Published by-, Chaukhambha Sanskrit Sansthan, Varanasi (India), Reprint; 2018. p. 183.

29. Yadavji Trikamji, Charaka-Samhita (Ayurveda-Dipika commentary by Chakrapanidatta), sharir sthana, sarirvichayasarir Adyayam-6/18; Published byChaukhambha Surbharati Prakashan, Varanasi (India), Reprint; 2000. p. 62.

30. Acharya Trikamji Yadavji, Sushruta-Samhita (NibandhaSamgraha commentary of Dalhana and Nyayachandrika Panjika of Gayadas on Nidana sthana), sutra sthana, Viparitaviparit Vranavijnaniya Adhyayam-28/7; Published by- Chaukhambha Orientalia, Varanasi, edition; 2002. p. 179.

31. Yadavji Trikamji, Charaka-Samhita (Ayurveda-Dipika commentary by Chakrapani Dutta), sutra sthana, Astoudariya Adhyayam-19/6; Published by- Chaukhambha Surbharati Prakashan, Varanasi (India), Reprint; 2000. p. 111.

32. Das Bhagwan, Charaka Samhita (text with English translation and critical exposition based on Chakrapani Dutta's Ayurveda Dipika), volume-II, Vimana sthana, Roganika Viman-6/5-6; published by-Chaukhambha Sanskrit series office, Varanasi (India), Reprint; 2018. p. 186-187.

33. Das Bhagwan, Charaka Samhita (text with English translation and critical exposition based on Chakrapani Dutta's Ayurveda Dipika), volume-II, Roganika Viman-6/6; Published by- Chaukhambha Sanskrit series office, Varanasi (India), Reprint; 2018. p. 185-86.

34. Pt. Hari Sadashiva Shastri Paradakara, Ashtanga-Hridaya (Sarvanga Sundari and Ayurveda Rasayana commentary by Arunadatta and Hemadri), sutra sthana, Doshadivijnaniya Adhyayam-11/43-44; Published by- Chaukhambha Sanskrit Sansthan, Varanasi (India), Reprint; 2018. p. 191.

35. Yadavji Trikamji Acharya, Charaka-Samhita (AyurvedaDipika commentary by Chakrapani Dutta), chikitsa sthana, Grahani roga Chikitsa Adhyayam-15/9-21; Published by-
Chaukhambha Surbharati Prakashan, Varanasi (India), Reprint; 2000. p. 513.

36. Niranjanadeba Ayuvedalamkar, Prakrita Doshavijnan, Tridosha Parichaya-1; Published by-Ayurvedic and Tibbi Academy Uttar Pradesh, Varanasi, $1^{\text {st }}$ Edition; 1971. p. 22-23.

37. Niranjanadeba Ayuvedalamkar, Prakrita Doshavijnan, Tridosha Parichaya-; Published by- Ayurvedic and Tibbi Academy Uttar Pradesh, Varanasi, $1^{\text {st }}$ Edition; 1971. p. 2223

38. Ayurveda Acharya Yadu Nandan Upadhyaya, Madhava Nidanam, (Madhu Kosha Sanskrit Commentary by Vijay Rakshita and Srikanta Dutta, Vidyotini Hinditikiya Nabin Vaijnanika Vimarshana by Shri Sudarshana Shastri), Prathama Bhaga (Purvardha), Panchanidanlakshanam-1/10; Published by- Chaukhambha Sanskrit Bhawan, Varanasi, Reprint; 2016. p. 35.

39. Yadavji Trikamji Acharya, Charaka-Samhita (AyurvedaDipika Commentary by Chakrapani Dutta), Sutra sthana, Kiyantushirasiya Adhyayam-17/62; Published byChaukhambha Surbharati Prakashan, Varanasi (India), Reprint; 2000. p. 102.

40. Yadavji Trikamji Acharya, Charaka-Samhita (AyurvedaDipika Commentary by Chakrapani Dutta), Vimana sthana, Rasa vimana Adhyayam-1/5; Published by- Chaukhambha Surbharati Prakashan, Varanasi (India), Reprint; 2000. p. 231.

41. Yadavji Trikamji Acharya, Charaka-Samhita (AyurvedaDipika Commentary by Chakrapani Dutta), Sutra sthana, Kiyantushirasiya Adhyayam-17/112-114; Published byChaukhambha Surbharati Prakashan, Varanasi (India), Reprint; 2000. p. 333.

42. Hari Sadashiva Shastri Paradakara, Ashtanga-Hridaya (Sarvanga Sundari and Ayurveda Rasayana Commentary) Sutra Sthana, Doshabhediya Adhyayam-12/17-18; Published by- Chaukhambha Sanskrit Sansthan, Varanasi (India); 2018. p. 195.

43. Acharya Trikamji Yadavji, Sushruta-Samhita, (NibandhaSamgraha Commentary of Dalhana and Nyayachandrika Panjika of Gayadas on Nidana sthana), Sharir sthana, Siravarna Vibhakti Sarir-7/16-17; Published byChaukhambha Orientalia, Varanasi, edition; 2002. p. 367377.

44. Niranjanadeba Ayuvedalamkar, Prakrita Doshavijnan, Tridosha Ki Vividhabastha, Published by- Ayurvedic and Tibbi Academy Uttar Pradesh, Varanasi, $1^{\text {st }}$ Edition; 1971. p. 83-84.

45. Niranjanadeba Ayuvedalamkar, Prakrita Doshavijnan, Prakrita Vata; Published by- Ayurvedic and Tibbi Academy Uttar Pradesh, Varanasi, $1^{\text {st }}$ Edition; 1971. p. 99-103.

46. Yadavji Trikamji Acharya, Charaka-Samhita (AyurvedaDipika Commentary by Chakrapani Dutta), Sutra sthana, Khuddak Chatushpada Adyayam-9/4; Published byChaukhambha Surbharati Prakashan, Varanasi (India), Reprint; 2000. p. 102.

47. Yadavji Trikamji Acharya, Charaka-Samhita (AyurvedaDipika Commentary by Chakrapani Dutta), Sharir sthana, Sharirvichaya Sarir-6/18; Published by- Chaukhambha Surbharati Prakashan, Varanasi (India), Reprint; 2000. p. 333.

48. Hari Sadashiva Shastri Paradakara, Ashtanga-Hridaya (Sarvanga Sundari and Ayurveda Rasayana Commentary) Sutra Sthana, Ayushkamiya Adhyayam-1/6, Published byChaukhambha Sanskrit Sansthan, Varanasi (India), Reprint; 2018. p. 7-8.

49. Niranjanadeba Ayuvedalamkar, Prakrita Doshavijnan, Tridosha Parichaya; Published by- Ayurvedic and Tibbi Academy Uttar Pradesh, Varanasi, $1^{\text {st }}$ Edition; 1971. p. 2324. 
50. Yadavji Trikamji Acharya, Charaka-Samhita (AyurvedaDipika Commentary by Chakrapani Dutta), Vimana sthana, Rasaviman-1/5; Published by- Chaukhambha Surbharati Prakashan, Varanasi (India), Reprint; 2000. p. 231.

51. Yadavji Trikamji Acharya, Charaka-Samhita (AyurvedaDipika Commentary by Chakrapani Dutta), Sutra sthana, Dirghamjibitiya Adhyayam-1/40; Published byChaukhambha Surbharati Prakashan, Varanasi (India), Reprint; 2000. p. 13.

52. Yadavji Trikamji Acharya, editor, Charaka-Samhita (Ayurveda-Dipika commentary by Chakrapani Dutta), sharir sthana, Sarirsamkhya Sarir-7/14; Published byChaukhambha Surbharati Prakashan, Varanasi (India), Reprint; 2000. p. 339.

53. Niranjanadeba Ayuvedalamkar, Prakrita Doshavijnan, Tridosha Parichaya-1, Published by- Ayurvedic and Tibbi Academy Uttar Pradesh, Varanasi, $1^{\text {st }}$ Edition; 1971. p. 22324.

54. Acharya Trikamji Yadavji, Sushruta-Samhita (NibandhaSamgraha Commentary of Dalhana and Nyayachandrika Panjika of Gayadas on Nidana sthana), Sharir sthana,
Sarbabhutachinta Sarir-1/3; Published by- Chaukhambha Orientalia, Varanasi, edition; 2002. p. 339-340.

55. Das Bhagwan, Charaka Samhita, (Text with English Translation and Critical Exposition Based on Chakrapani Dutta's Ayurveda Dipika,) Volume-I, Sutra sthana, Atreyabhadrakapiya Adhyayam-26/45-46; Published byChaukhambha Sanskrit series office, Varanasi (India), Reprint; 2018. p. 439.

56. Das Bhagwan, Charaka Samhita, (text with English translation and critical exposition based on Chakrapani Dutta's Ayurveda Dipika), volume-III, chikitsa sthana, Jwara Chikitsa Adhyayam-3/127; published by- Chaukhambha Sanskrit series office, Varanasi (India), Reprint; 2018. p. 145.

\section{Cite this article as:}

Afroja Yeasmin Akhtar Roji and Murlidhar Paliwal. Concept of Dosha in Ayurveda: A Review. Int. J. Res. Ayurveda Pharm. 2020;11(6):105-111 4343.1106196

\section{Source of support: Nil, Conflict of interest: None Declared}

Disclaimer: IJRAP is solely owned by Moksha Publishing House - A non-profit publishing house, dedicated to publishing quality research, while every effort has been taken to verify the accuracy of the content published in our Journal. IJRAP cannot accept any responsibility or liability for the site content and articles published. The views expressed in articles by our contributing authors are not necessarily those of IJRAP editor or editorial board members. 